DOI: $\underline{10.28925 / 2312-5829.2021 .36}$

УДК 373.5

\title{
OKSANA BUTURLINA
}

Communal Institution of Higher Education

«Dnipro Academy of Continuing Education»

of Dnipropetrovsk Regional Council, Dnipro, Ukraine

buturlina71@gmail.com, ORCID: 0000-0002-9603-4752

\section{TETIANA LYSOKOLENKO}

Communal Institution of Higher Education

«Dnipro Academy of Continuing Education»

of Dnipropetrovsk Regional Council, Dnipro, Ukraine

lusokolenko@gmail.com,ORCID: 0000-0003-1545-8682

\section{Serhii Dovhal}

Communal Institution of Higher Education

«Dnipro Academy of Continuing Education»

of Dnipropetrovsk Regional Council, Dnipro, Ukraine

sdovgal2010@gmail.com,ORCID: 0000-0002-7134-7488

\section{RESEARCH OF STEM EDUCATION IMPLEMENTATION IN UKRAINE: GENDER ASPECT}

Given the importance of overcoming the shortage of staff in the STEM market, this study aims to present the analysis in terms of gender characteristics that affect the choice of profession by high school students. The sociological survey was conducted using the online method - a survey using Google Forms service. Four hundred and thirty-one respondents were 11th grade students (including 230 girls and 201 boys) who studied in experimental secondary schools in Dnipropetrovsk region participated in the survey. The methodology covers such aspects, as students' knowledge of mathematics and natural sciences; career interests in the context of students' motivation in studying STEM disciplines; students' knowledge of the requirements for STEM careers. In the research, by comparing the answers of male and female respondents, it became possible to draw parallels on gender differences in the field of professional preferences of the surveyed students in the context of STEM education. Thus, after conducting research on gender specifics that influence the choice of profession in STEM areas by high school students, we can talk about the following. The obtained results show that there are insignificant differences between girls and boys in the field of interest in natural and mathematics sciences and technological education with an advantage in favor of boys. The results 
suggest that the choice of profession by high school students in the field of STEM is influenced by awareness of the prospects of the future career and self-confidence, which is connected with students' academic success in mathematics, science and technology education. The study is one of the pilot projects in Ukraine. To further delve into the problem, it is necessary to conduct a regression analysis of several variables, in particular, the study of the relationship between career planning in the field of STEM and the type of residence of students (metropolis, city, town, village) and analysis of STEM preferences with reference to academic success of boys and girls.

Keywords: education in Ukraine, gender, innovative technologies, STEM.

(C) Buturlina Oksana, Lysokolenko Tetiana, Dovhal Serhii, 2021

Introduction. Among the key areas of the development of STEM education identified by the world community along with the development of innovative educational programs, professional development of teachers, development of scientific and technical creativity and career support for young people, the involvement of girls and women in STEM education and STEM careers plays an important role. Bridging the gender gap is considered a promising area of personnel policy in the STEM areas.

Gender stereotypes are part of modern gender culture, which is formed by such traditional institutions as language, religion, school, family and upbringing (Lauretis, 1987). In the $20^{\text {th }}-21^{\text {st }}$ centuries, traditional and new media are added to this list. Gender prejudices and beliefs are an important phenomenon that hinders gender equality in professional activities. The formation of life and career strategies of adolescents is under the influence of "others" - parents, friends, teachers and peers. Parents and teachers construct certain gender expectations towards girls and boys in the process of interaction. These expectations are assimilated and transmitted as their own. It is therefore important what ideas parents and teachers carry through their own way of life, positions and ideas. The lens theory of culture focuses on the way of establishing the differences between women and men (Bem, 2004). Gender ideology at the subconscious level may form an idea of the world of male and female occupations. These are the so-called "great gender narratives", which are difficult to transform because they are passed down from generation to generation and continue to be reproduced in the cultural texts of modern media. As a result, the persistence of the phenomenon of polarization of scientific careers on the basis of gender is a disproportionate distribution of men and women in various fields of knowledge.

Insufficient representation of women in science, technology, engineering and mathematics (STEM) is problematic, given the economic and social inequalities it contributes to and the growing global importance of STEM careers (Bottia et al., 2015). The school remains one of the powerful "genderized" institutions where "big gender narratives" are strengthened and reproduced. Studying there is one of the key stages in the formation of gender identity and gender roles, and in fact gender socialization, which sometimes occurs by blocking equality. Aiming to find the cause of gender inequality, within the project "Alphabet of Gender Equality in Education" the project situations were formed that allowed to analyze the self-esteem of students in relation to their mathematical abilities. The gender difference in self-confidence and self-awareness of one's abilities is 
especially significant when considering the skills of solving applied mathematical problems of gender-stereotypical content. It was found that $67 \%$ of boys, as opposed to $44 \%$ of girls are confident in the calculation of gasoline consumed by the car. Only $75 \%$ of girls compared to $84 \%$ of boys reported that they were confident in calculating the cost of TV after a 30\% discount (OECD, 2015). Girls' self-doubt leads to a gender imbalance in the development of various professions in higher education. On average, in OECD countries, men received engineering education three times more than women did (OECD, 2016).

At the same time, boys in Ukraine are more likely than girls to hope for higher education graduation. In Ukraine, most girls with low socio-economic status aspire to enter university, while among boys, on the contrary, those with a high socio-economic status index are more likely to hope for higher education. The difference between the aspirations of boys and girls can also apply to the fields of education: in Ukraine, girls more often choose philological and economic specialties, and boys - engineering and sciences (OECD, 2016).

Accordingly, given the relevance of the gender aspect in the context of STEM education, the importance of researching gender specificities that influence the choice of profession in STEM areas by high school students is obvious.

In Ukraine, despite the very young age of STEM, implementation programs have been developed at the state level and at the level of the STEM Coalition of Ukraine, which unites the efforts of STEM education stakeholders of the private sector and employers. Through the efforts of the institutions of the Ministry of Education and Science that promote the development of this innovation, the constituent documents regulating the implementation of STEM education in educational institutions of Ukraine have been developed (IECM, 2015, 2019; Order of the Ministry 2016, 2017). Thus, in particular, the proposed research topic is the result of long-term work of educators of Dnipropetrovsk region who have already conducted a lot of research (see Table 1) on the state of STEM education in Ukraine. They have noticed that there is a significant difference in perception, understanding and vision in the field of engineering for girls and boys, which is the reason for this study (Buturlina, Lysokolenko \& Dovgal, 2019).

Table 1.

\section{STEM research on the example of Dnipropetrovsk region}

\begin{tabular}{|l|l|l|l|l|}
\hline Respondents & $\begin{array}{l}\text { Numb } \\
\text { er of } \\
\text { respo } \\
\text { ndent } \\
\text { S }\end{array}$ & Purpose of the poll & Method & Dates \\
\hline $\begin{array}{l}\text { Principals, } \\
\text { coordinators and } \\
\text { teachers } \\
\text { experimental } \\
\text { schools }\end{array}$ & 230 & $\begin{array}{l}\text { Purpose of the study } \\
\text { of to identify the level } \\
\text { of motivation and } \\
\text { technological readiness } \\
\text { of pedagogical workers }\end{array}$ & $\begin{array}{l}\text { Online google- } \\
\text { with service } \\
\text { form } \\
\text { author's } \\
\text { questionnaire }\end{array}$ & April 2017 \\
\hline
\end{tabular}




\begin{tabular}{|c|c|c|c|c|}
\hline & & $\begin{array}{l}\text { for experimental work } \\
\text { on the introduction of } \\
\text { STEM education } \\
\text { innovative model in } \\
\text { regional secondary } \\
\text { education institutions }\end{array}$ & ) & \\
\hline $\begin{array}{l}10 \text { th form pupils } \\
\text { of } \\
\text { Dnipropetrovsk } \\
\text { region general } \\
\text { education } \\
\text { institutions }\end{array}$ & 670 & $\begin{array}{l}\text { Purpose of the research } \\
\text { was to investigate } \\
\text { students' public opinion } \\
\text { about studying subjects } \\
\text { and selecting STEM- } \\
\text { professions }\end{array}$ & $\begin{array}{l}\text { Online poll } \\
\text { with google- } \\
\text { form service } \\
\text { (author's } \\
\text { questionnaire } \\
\text { ) }\end{array}$ & October 2017 \\
\hline $\begin{array}{l}\text { Expert Group: } \\
\text { Management of } \\
\text { leading } \\
\text { enterprises of } \\
\text { Ukraine; } \\
\text { Employees of } \\
\text { higher } \\
\text { educational } \\
\text { institutions of } \\
\text { Ukraine; } \\
\text { The heads of } \\
\text { local education } \\
\text { authorities; } \\
\text { Representatives } \\
\text { of employment } \\
\text { centers }\end{array}$ & 40 & $\begin{array}{l}\text { Purpose of the survey } \\
\text { was to study the } \\
\text { experts opinions of } \\
\text { different categories on } \\
\text { the main problems and } \\
\text { perspectives of } \\
\text { introducing STEM- } \\
\text { education at the regional } \\
\text { level (on the example of } \\
\text { Dnipropetrovsk region). }\end{array}$ & $\begin{array}{l}\text { Online poll } \\
\text { with google- } \\
\text { form service } \\
\text { (author's } \\
\text { questionnaire } \\
\text { ) }\end{array}$ & April 2018 \\
\hline $\begin{array}{l}\text { Parents of high } \\
\text { school students }\end{array}$ & 486 & $\begin{array}{l}\text { The purpose of the } \\
\text { survey was to study the } \\
\text { level of influence of } \\
\text { parents on the } \\
\text { professional orientation } \\
\text { of high school students. }\end{array}$ & $\begin{array}{l}\text { Online poll } \\
\text { with google- } \\
\text { form service } \\
\text { (author's } \\
\text { questionnaire } \\
\text { ) }\end{array}$ & October 2018 \\
\hline $\begin{array}{l}\text { High } \\
\text { students }\end{array}$ & 431 & $\begin{array}{l}\text { The purpose of the } \\
\text { study was to track the } \\
\text { dynamics of the impact }\end{array}$ & $\begin{array}{l}\text { Online poll } \\
\text { with google- } \\
\text { form service }\end{array}$ & February 2019 \\
\hline
\end{tabular}




\begin{tabular}{|l|l|l|l|}
\hline & $\begin{array}{l}\text { of STEM education on } \\
\text { the vocational guidance } \\
\text { of high school students } \\
\text { in experimental schools. }\end{array}$ & questionnaire \\
& & \\
\hline
\end{tabular}

Literature Review. The range of researches of gender aspects in the field of STEM is very wide and diverse. Let us try to present its different sides.

The problem of gender imbalance in the process of learning different professions in higher education, which is also referred to as gender asymmetry, is being studied (Xie, Fang \& Shauman, 2015). The authors state that differences in the socio-economic status of the family, race and gender persist in education.

The paper "Gender Differences in Fields of Study: The Role of Significant Others and Rational Choice Motivations" examines gender differentiation as the result of socialization processes and the factor of reasonable choice (as a combination of benefits and expectations of failure). The authors emphasize the role of gender stereotypes and role expectations: girls do not look like those who choose STEM, while boys do not see themselves choosing the humanities, which is the reason for different professional strategies (Gabay -Egozi, Shavit \& Yaish, 2015).

The works by Perez, Cromley \& Kaplan (2014), Wang and Degol (2013, 2017), Allen \& Eisenhart (2017) study the causes of underrepresentation of girls and women in the STEM fields.

Thus, in particular, the paper "The role of identity development, values, and costs in college STEM retention" considers the relationship of motivational beliefs of students with their academic success in the field of STEM (Perez, Cromley \& Kaplan 2014).

The authors of the research "Motivational pathways to STEM career choices: Using expectancy-value perspective to understand individual and gender differences in STEM fields" focus on the analysis of barriers and factors (sociocultural, contextual, biological and psychological) affecting individual education and career choices in the context of gender differences (Wang, \& Degol, 2013). In the study "Gender Gap in Science, Technology, Engineering, and Mathematics (STEM): Current Knowledge, Implications for Practice, Policy, and Future Directions", the authors identify the following causes of underrepresentation of girls and women in STEM areas. Namely - cognitive, professional interests and preferences, life values regarding the balance between career and family, ideas about one's abilities and gender stereotypes and beliefs (Wang, \& Degol, 2017). Allen \& Eisenhart, (2017) in turn, analyze the opportunities of girls in choosing a profession in the field of STEM, emphasizing the role of the school in supporting certain gender stereotypes in the process of choosing a profession by girls.

The study of gender preferences is covered in the work "Not Lack of Ability but More Choice: Individual and Gender Differences in Choice of Careers in Science, Technology, Engineering, and Mathematics". The authors conclude that there is an interdependence between women's verbal abilities and their propensity to choosing a profession in science, technology and mathematics. The authors note that people with high levels of math who also had high levels of verbal ability were less likely to pursue a career 
in STEM than people who also had high levels of math but had moderate verbal skills (Wang, Eccles \& Kenny, 2013).

Bottia et al., (2015) based on the study conclude that STEM teachers in senior female classes play a key role in girls' decisions on choosing a STEM profession. Increasing the proportion of women teachers in STEM-related subjects increases girls' chances of choosing a STEM profession. In turn, the chances for boys to choose STEM professions do not depend on the share of women teachers of STEM subjects.

Blums et al., (2017) have found a correlation between the social situation of student development and the level of success in the field of STEM subjects.

Based on a study of the personal stories of women successful in STEM industries, Zeldin \& Pajares (2000) conclude that women's verbal beliefs and alternative experiences are critical sources for convincing women of their effectiveness. Belief in one's own selfefficacy leads to perseverance and persistence in the workplace. These indicators are especially important for those women who work in areas traditionally focused on men (Zeldin \& Pajares, 2000).

Various options for integrating STEM into education and the workplace are highlighted in the following researches: "A Conceptual Framework for STEM Integration Into Curriculum Through Career and Technical Education" (Asunda, 2014), "Practicing engineering while building with blocks: identifying engineering thinking" (Bagiati \& Evangelou, 2016), "Effects of integrative approaches among science, technology, engineering, and mathematics (STEM) subjects on students' learning: A preliminary metaanalysis" (Becker, \& Park 2011), "Transfer of Learning: Connecting Concepts during Problem Solving" (Dixon \& Brown, 2012), "An analysis of Australian STEM education strategies. Policy Futures in Education" (Murphy at al., 2018), "Makerspace in STEM for girls: A physical space to develop twenty-first-century skills" (Sheffield at al., 2017), "The Effect of STEM Project Based Learning on Self-Efficacy among High-School Physics Students" (Samsudin at al., 2020). In the context of the given research topic, we should refer to the work of Ceci \& Williams (2007), in which the authors discuss the ambiguity of gender differences, especially in the last 30 years, when there have been gender changes in many industries. The authors believe that different fields of science are not gender neutral, so girls and boys differently evaluate their abilities in technical and humanities.

Thus, the review of the literature emphasizes the relevance of the development of gender issues in the STEM field. As there is an urgent problem in overcoming the shortage of staff in the STEM market, it is important to explore the gender specificities that influence the choice of profession in the STEM field by high school students.

Methods. In February, 2019, educators of Dnipropetrovsk region within the regional experiment ("Scientific and methodological principles of creating an innovative model of STEM education") conducted a study "The impact of STEM education on vocational guidance of high school students". In the research, by comparing the answers of male and female respondents, it became possible to draw parallels on gender differences in the field of professional preferences of the surveyed students in the context of STEM education. The aim was to investigate the gender characteristics that influence the choice of profession in STEM fields by high school students. 
The Commission on Innovation of the Dnieper Academy of Continuing Education approved this study. Permission to collect data in schools was obtained from school board leaders and parents. Based on the literature, we partly took into account the experience of the study by Blotnicky, Odendaal, French \& Joy (2018) in which the authors considered the question: "Who? What? And how does it affect the choice of young people in the field of STEM?". The reserchers point out that gender differences are important because STEM stereotypes are shifted towards men (Blotnicky et al., 2018) and we note that in this study the gender aspect has been left without due attention. Hence, based on our own study of the impact of STEM education on the professional orientation of high school students, in our research we offer an analytical section, which is dedicated to the interpretation of gender characteristics in choosing a profession in the field of STEM.

The study covered three areas of interest (in the context of gender comparisons): students' knowledge in disciplines directly related to STEM, namely, mathematics and science; career interests of students, in the sense of their motivation to study STEM disciplines; students' knowledge of the requirements in the professional areas of STEM.

The sociological survey was conducted using the online method - a survey using Google Forms service. Four hundred and thirty-one respondents were 11th grade students (including 230 girls and 201 boys) who studied in experimental secondary schools in Dnipropetrovsk region participated in the survey. The distribution of respondents by place of residence is shown in Chart 1.

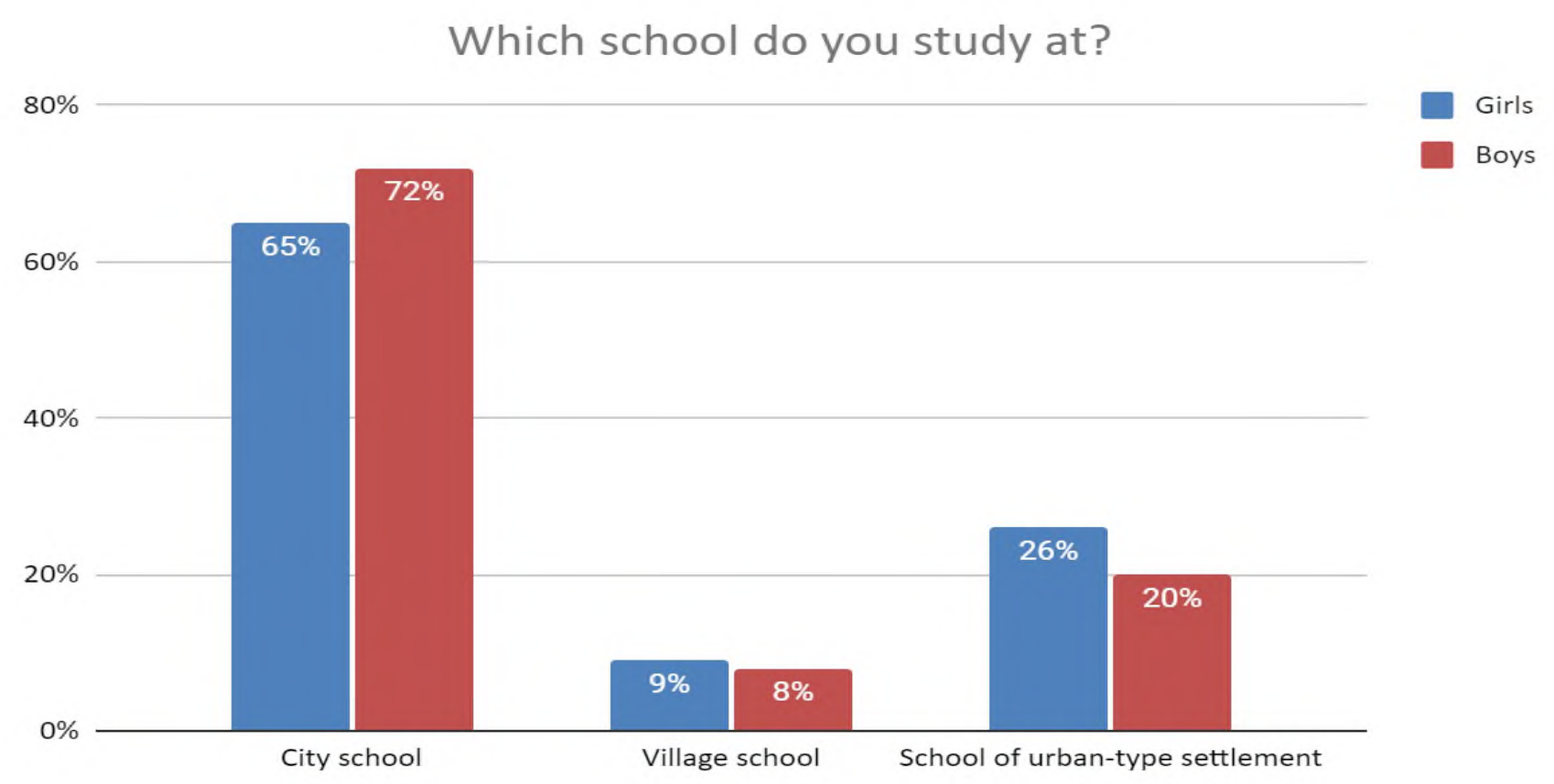

Chart 1 «Distribution of respondents by place of residence»

The survey was anonymous; the questions in the questionnaire were of different types: open-ended and close-ended, alternative and non-alternative questions.

Thus, the study of gender characteristics influencing the choice of profession in STEM fields by high school students was based on a comparative analysis of the answers of girls and boys to the following questions: 
1. What areas of STEM education are you most interested in? (close-ended question with alternative answers)

2. Do you agree that STEM specialists will be needed in the near future society? (close-ended question with non-alternative answers)

3. Do you agree that a successful career in the future requires good knowledge of mathematics, science and technology? (close-ended question with non-alternative answers)

4. Do you know where you can implement your knowledge in the field of STEM in the future? (close-ended question with non-alternative answers)

5. How interested are you in natural and mathematics sciences and technological education? (close-ended question with non-alternative answers)

6. Where, apart from school, do you get knowledge in natural and technological disciplines? (close-ended question with non-alternative answers)

7. Do you have the skills and qualities needed to work in science, technology and engineering? (close-ended question with non-alternative answers)

8. Would you like to choose a STEM profession? (close-ended question with nonalternative answers)

9. In your opinion, which of the listed professions are the most promising today? (open-ended question).

10. Which of the following tools of career guidance, in your opinion, are most conducive to professional self-determination? (close-ended question with non-alternative answers)

The gender aspect of these issues has not been studied in the context of Ukraine, which makes this study relevant for the education system of Ukraine and the whole world.

Findings. The results of the study showed that the surveyed 11th grade students are interested in different areas of STEM education. Most respondents, both boys and girls, are interested in areas such as programming, ICT, design and modeling. At the same time, the survey showed that there are some differences in the responses of female respondents and male respondents. Thus, girls are much more interested in ICT technologies than boys are, as indicated by $23 \%$ of girls surveyed, while among boys the figure is $12 \%$. The situation was similar with the indicator "scientific and technical creativity", which was indicated by $17 \%$ of girls and $9 \%$ of boys respectively. At the same time, boys more often prefer design - 19\% and programming 15\%. In addition, boys are more interested in the indicators of "career support" and "robotics" than girls are. See Chart 2 for details. 


\section{Areas of STEM education that respondents are interested in within the context of gender differences}

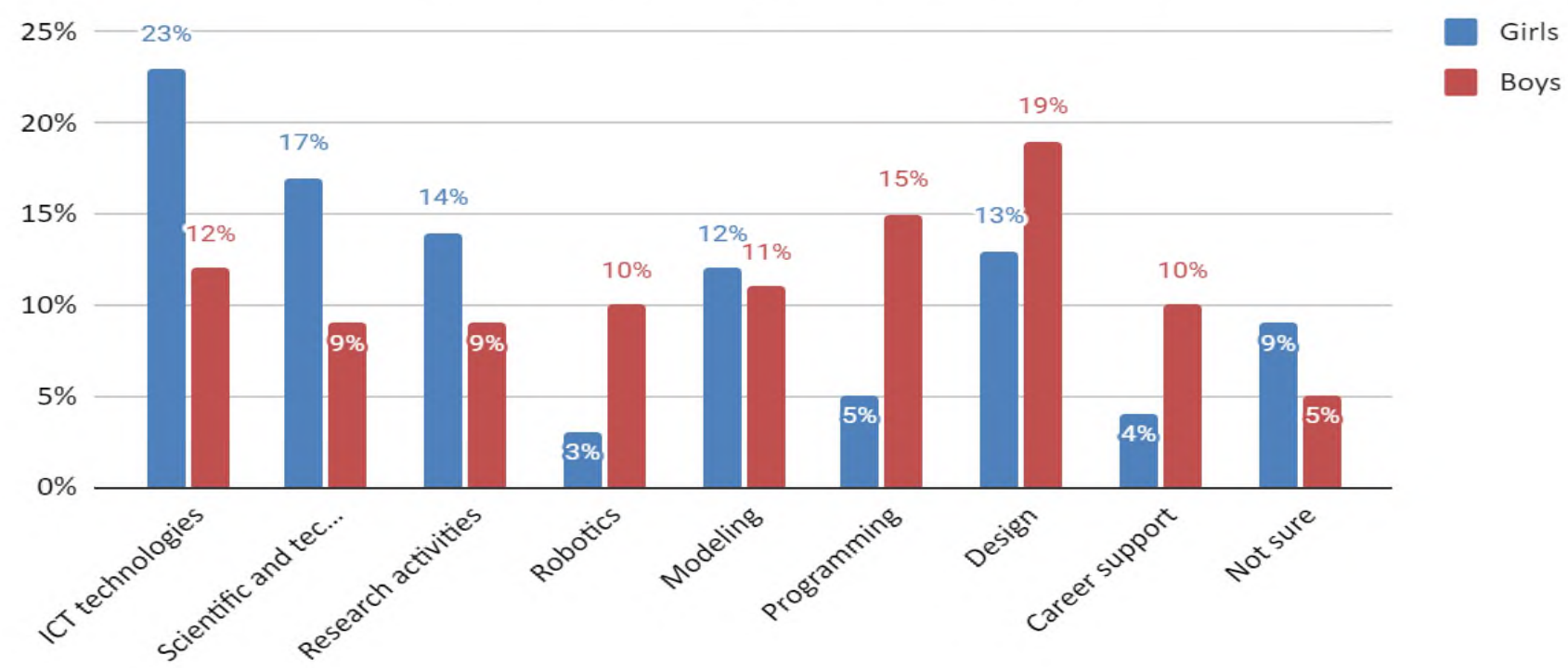

Chart 2. «Areas of STEM education that interest respondents most»

According to the results of the study, we can say that the female respondents and male respondents in the vast majority are sure that the future lies with the STEM industry. See Chart 3 for details.

Do you agree that STEM specialists (scientists, technologists, engineers) will be needed in the near future society?

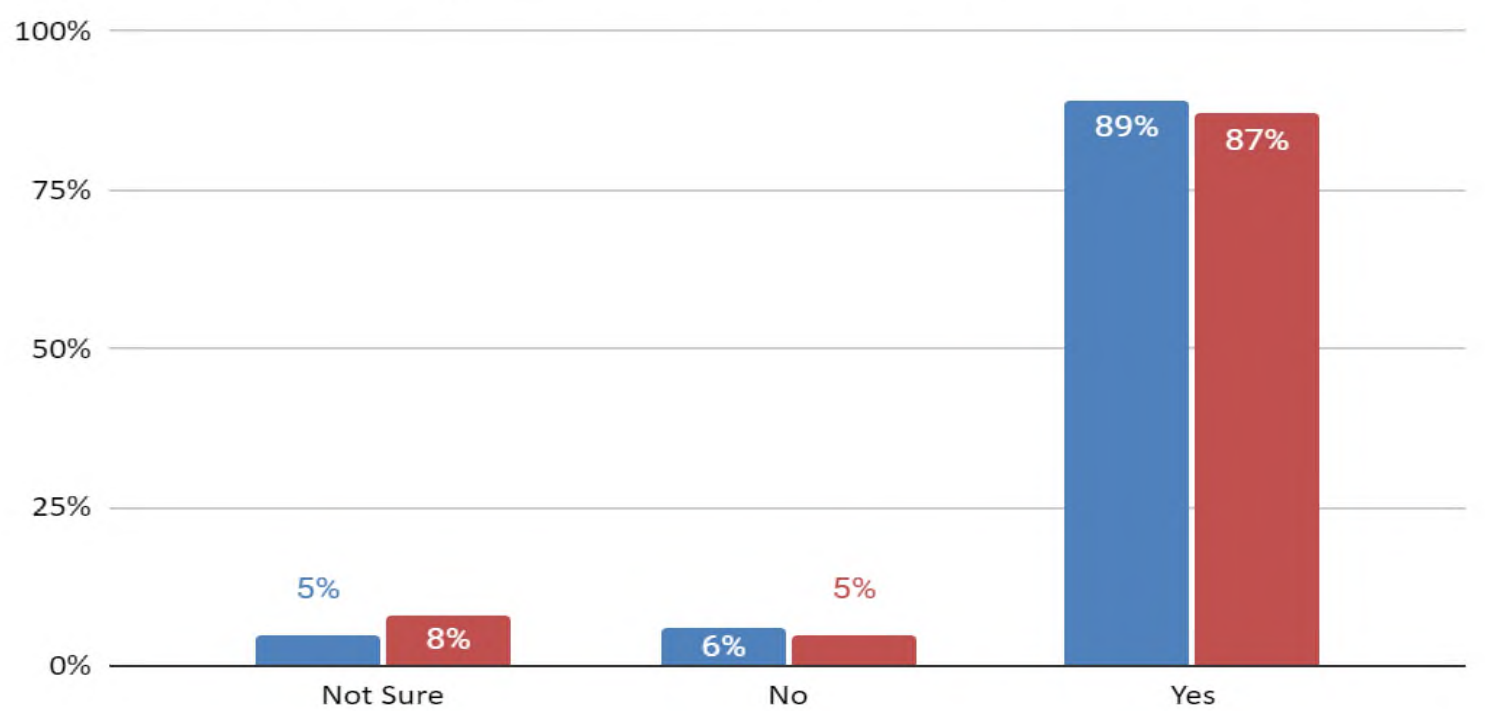

Chart 3. Respondents' answers to the question «Do you agree that STEM specialists will be needed in the near future society?»

In response to the question "Do you agree that a successful career in the future requires good knowledge of mathematics, science and technology?", we see that the majority of respondents agree with this statement, while $29 \%$ of girls and $21 \%$ of boys disagree. (Chart 4) 
Do you agree that a successful career in the future requires good knowledge of mathematics, science and technology?
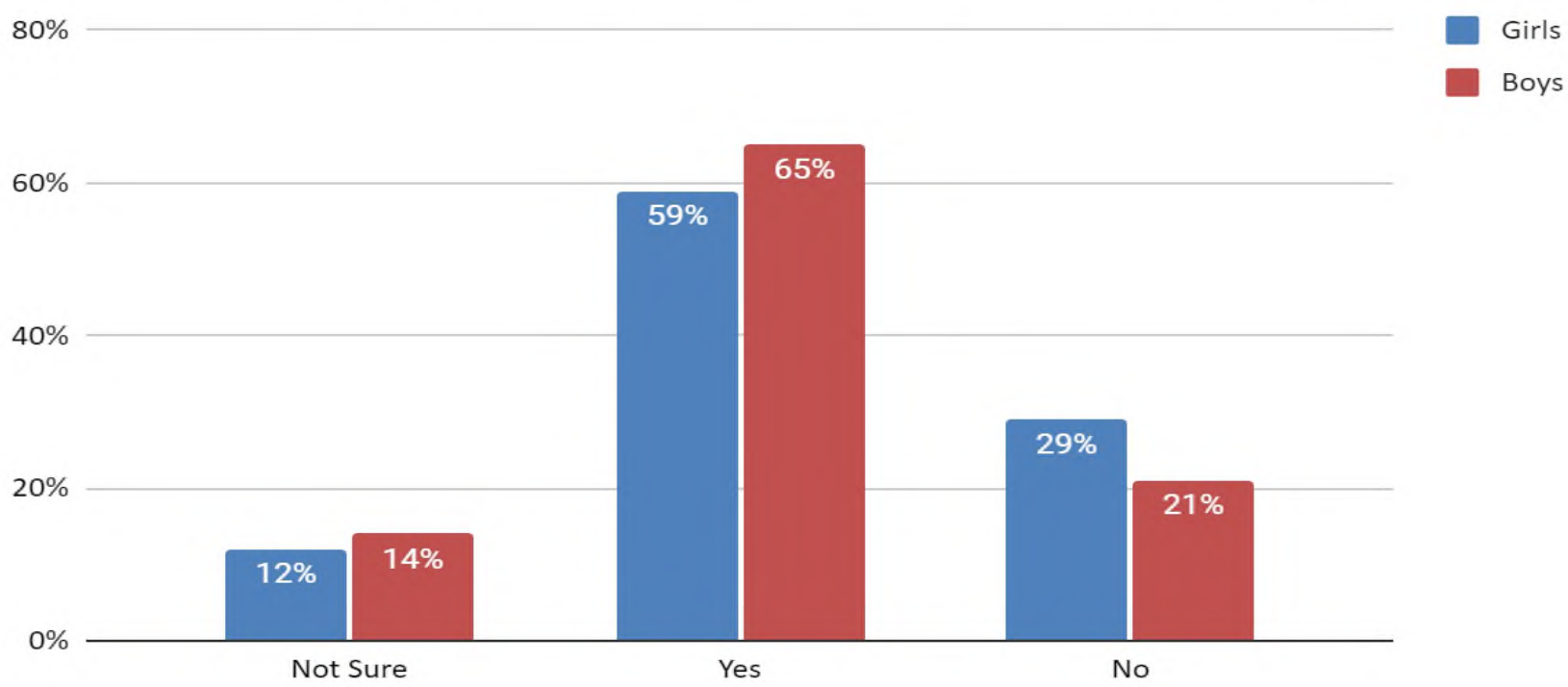

Chart 4. Respondents' answers to the question «Do you agree that a successful career in the future requires good knowledge of mathematics, science and technology ?»

In response to the question "Do you know where you can apply your knowledge in the field of STEM in the future?" we observe the following: more than $60 \%$ of all respondents consider themselves aware of this issue. This is stated by $63 \%$ of girls and $61 \%$ of boys. Slightly more girls (20\%) than boys (18\%) cannot answer the question. (Chart 5)
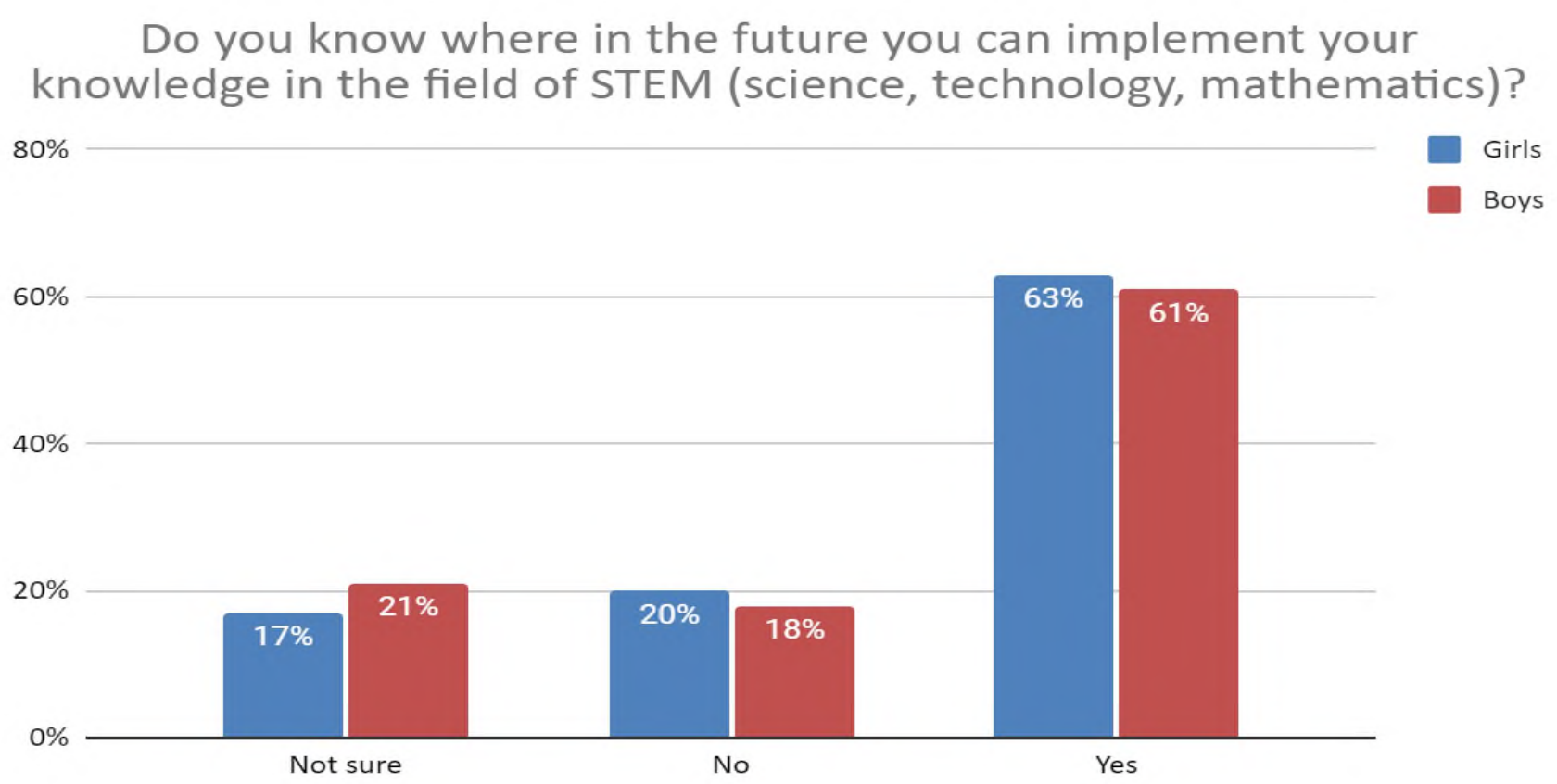

Chart 5. Respondents' answers to the question «Do you know where in the future you can implement your knowledge in the field of STEM (science, technology, mathematics)? »

There is a certain pattern in the answers to the questions about the level of interest in natural-mathematical disciplines and technological education. Thus, an equal number of girls and boys have chosen the position "I am not interested in learning at all" and "We 
would be more interested, but it all depends on the teacher". Almost identical number of girls and boys (32\% and 33\% respectively) have chosen the position "No more interested in other school subjects". However, $20 \%$ of girls and $31 \%$ of boys have indicated that these are their favorite areas of education. $26 \%$ of girls and $11 \%$ of boys have said that natural and mathematics sciences and technological education are difficult for them.

\section{(Chart 6)}

How interested are you in natural and mathematics sciences and technological education?

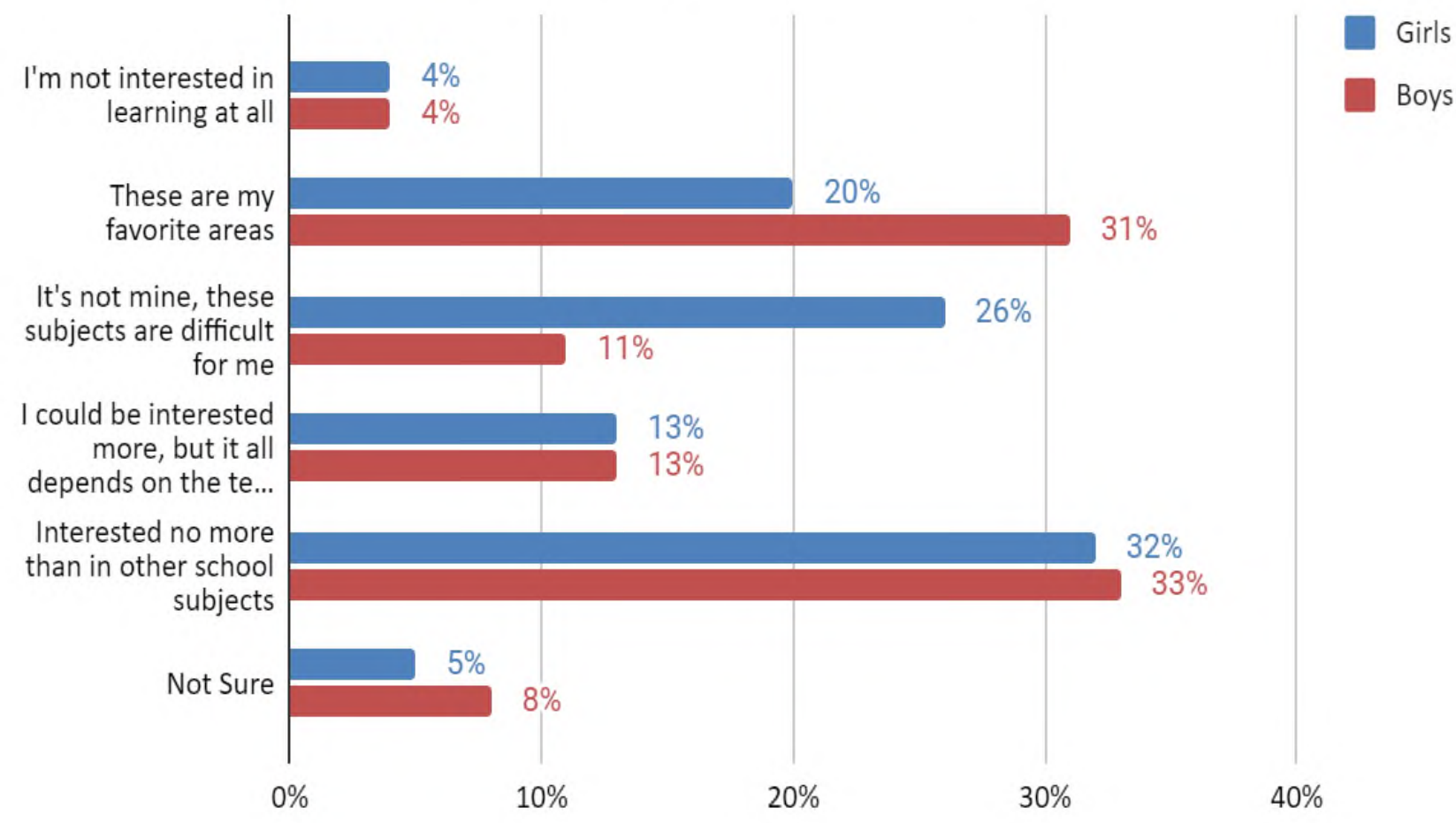

Chart 6. Respondents' answers to the question «How interested are you in natural and mathematics sciences and technological education?»

To the question "Where, apart from school, do you get knowledge in natural and technological disciplines?" girls most often have pointed to the positions "I am engaged in self-education" (33\%) and "in classes and electives" (33\%). At the same time, 20\% of girls cannot give a clear answer to this question. Notably, the answers of boys are also concentrated around these options, although among them there is a smaller percentage of those who have not decided on the answer and a higher percentage of those who are engaged in self-education, compared to girls (Chart 7). 


\section{Where, apart from school, do you get knowledge in natural and technological disciplines?}

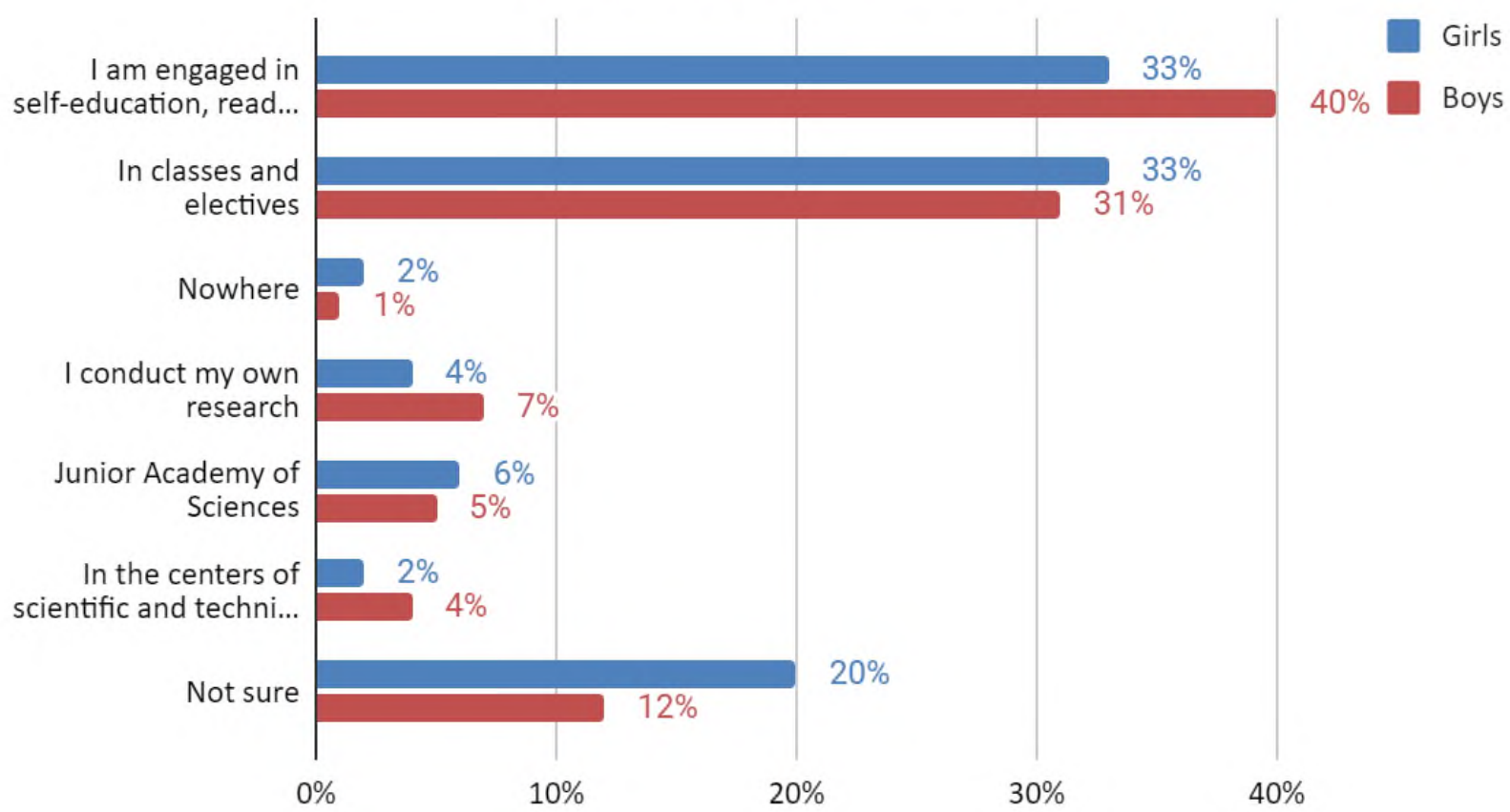

Chart 7. Respondents' answers to the question «Where, apart from school, do you get knowledge in natural and technological disciplines?»

Almost half of the respondents of both genders are certain that they have the skills needed to work in the STEM field. At the same time, 29\% of girls and 24\% of boys do not have such confidence. In addition, more than $20 \%$ of respondents of both genders have not decided on the answer to this question. (Chart 8)

Do you have the skills and qualities needed to work in science, technology and engineering?

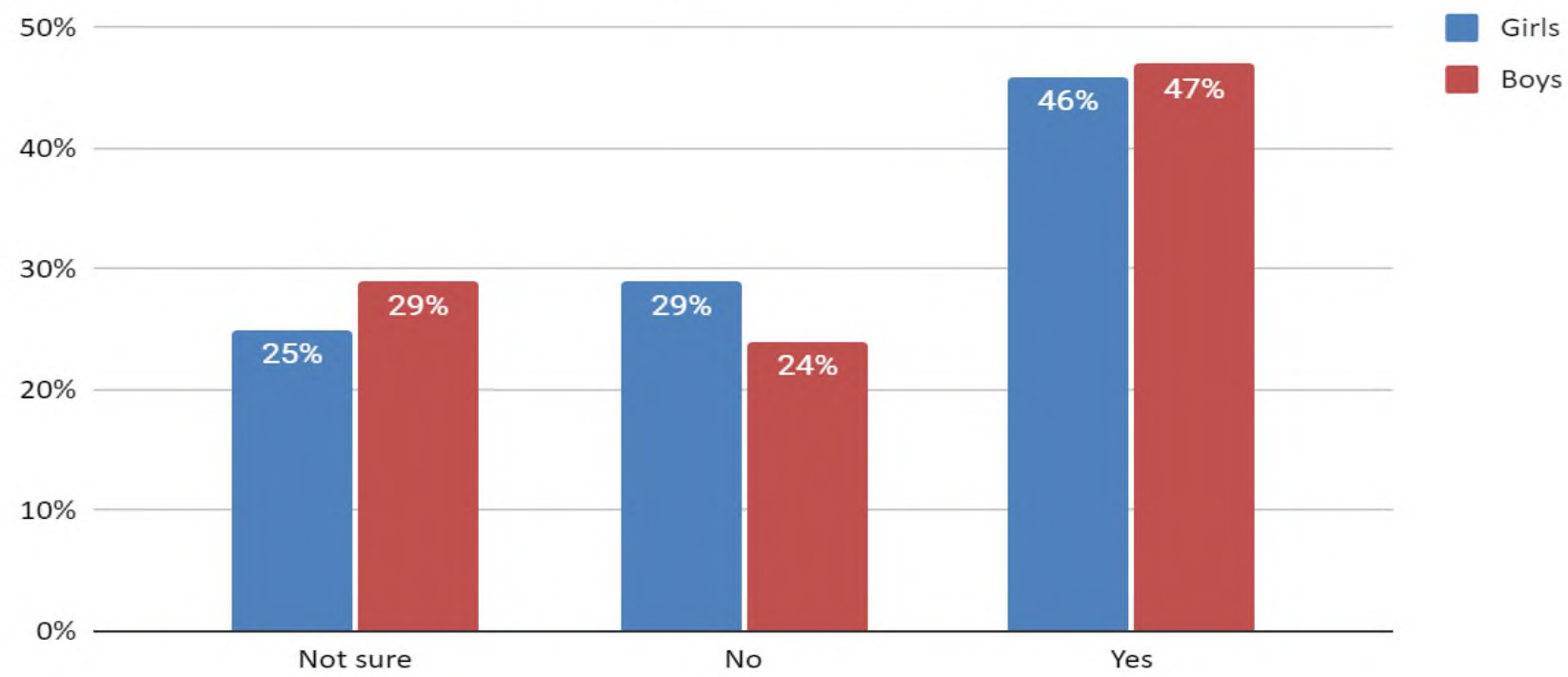

Chart 8. Respondents' answers to the question «Do you have the skills and qualities needed to work in science, technology and engineering?» 
$37 \%$ of girls and $21 \%$ of boys say that the obstacle in choosing professions related to STEM for them is the lack of the necessary amount of knowledge in the field of natural sciences and mathematics. Only $24 \%$ of girls and $37 \%$ of boys surveyed indicate that they are interested in these areas (Chart 9).

\section{Would you like to choose a STEM profession?}

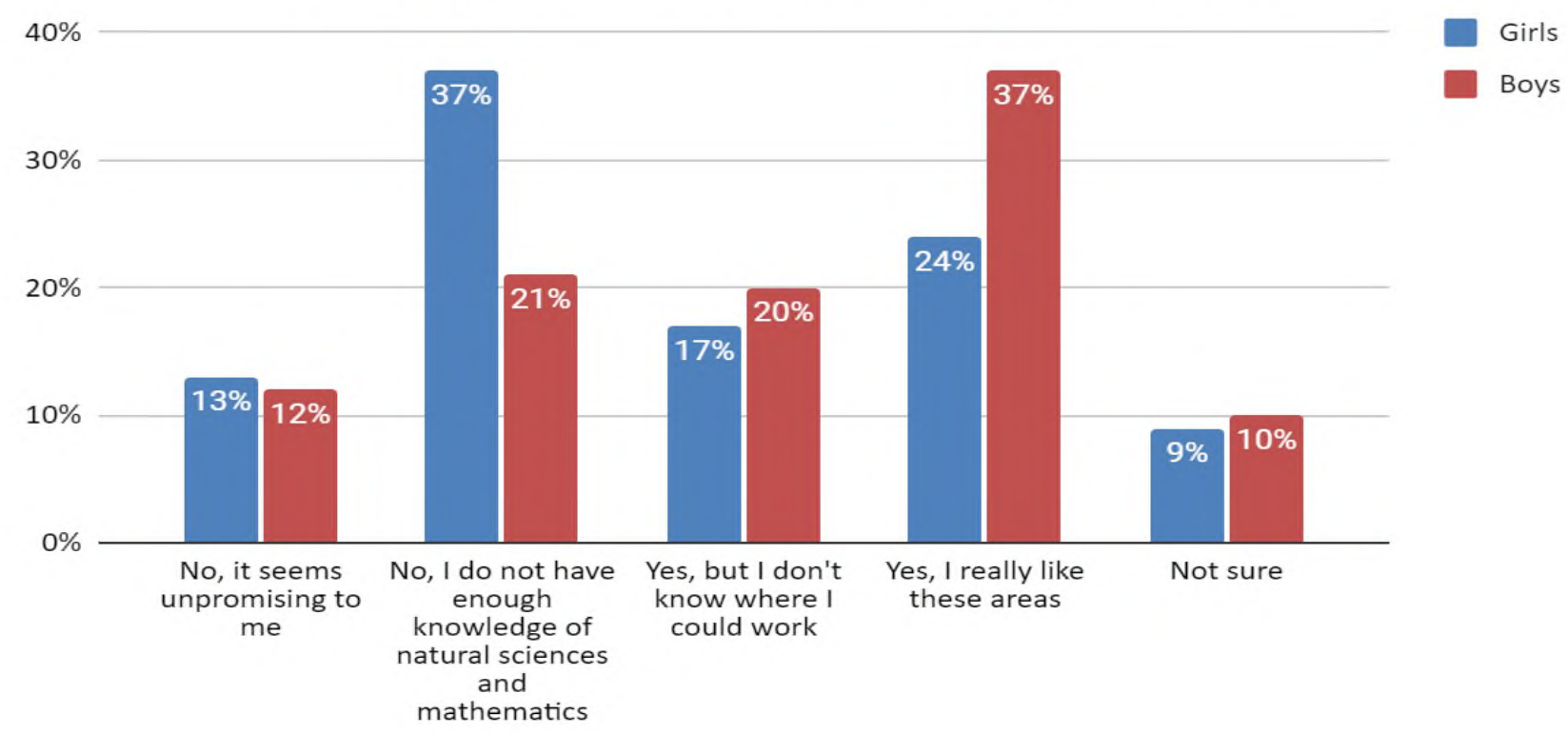

Chart 9. Respondents' answers to the question «Would you like to choose a STEM profession?»

Gender analysis of responses to students' perceptions of promising professions is as follows. Thus, we see that girls (42\%) indicate the profession of a doctor and $25 \%$ of girls indicate the profession of IT specialist. It should be noted that these positions are also more common in the answers of boys, but compared to girls, boys indicate the prospects of the medical profession less often (35\%) while the profession of IT specialist is chosen by boys more often (36\%). (Chart 10) 


\section{Which of the following professions do you think are the most} promising today?

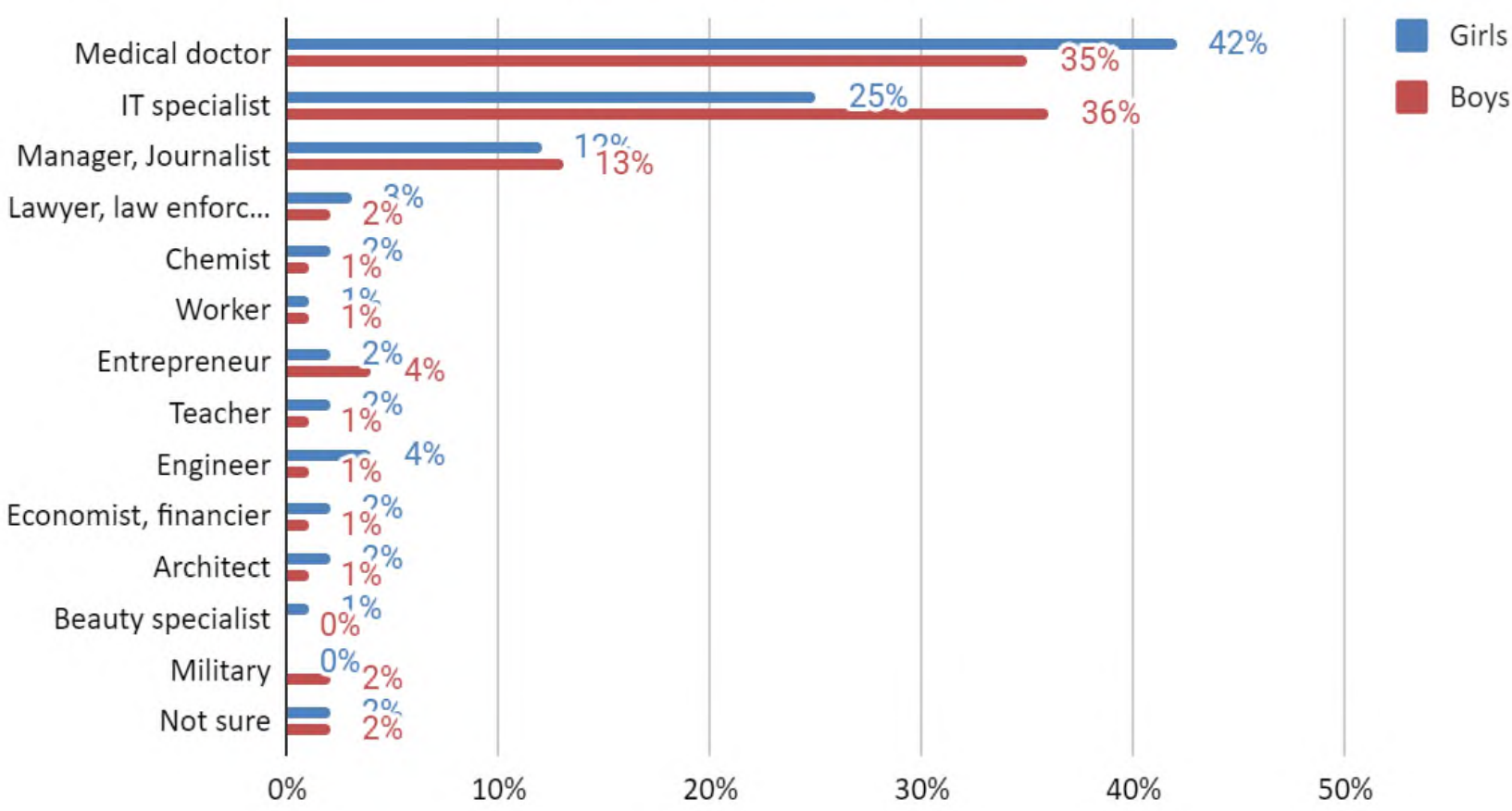

Chart 10. Respondents' answers to the question «Which of the following professions do you think are the most promising today?»

Since the STEM industry is closely linked to information technology and manufacturing, students were asked questions that helped to identify the effective career guidance mechanisms. The results show that for most girls (52\%) compared to boys (20\%) it is important to try yourself in a particular job. The gap in the answers "meetings with business leaders" and "self-determination trainings", which boys focus on more often than girls, is not so noticeable. (Chart 11). 


\section{Which of the following tools of career guidance, in your opinion, are most conducive to professional self-determination?}

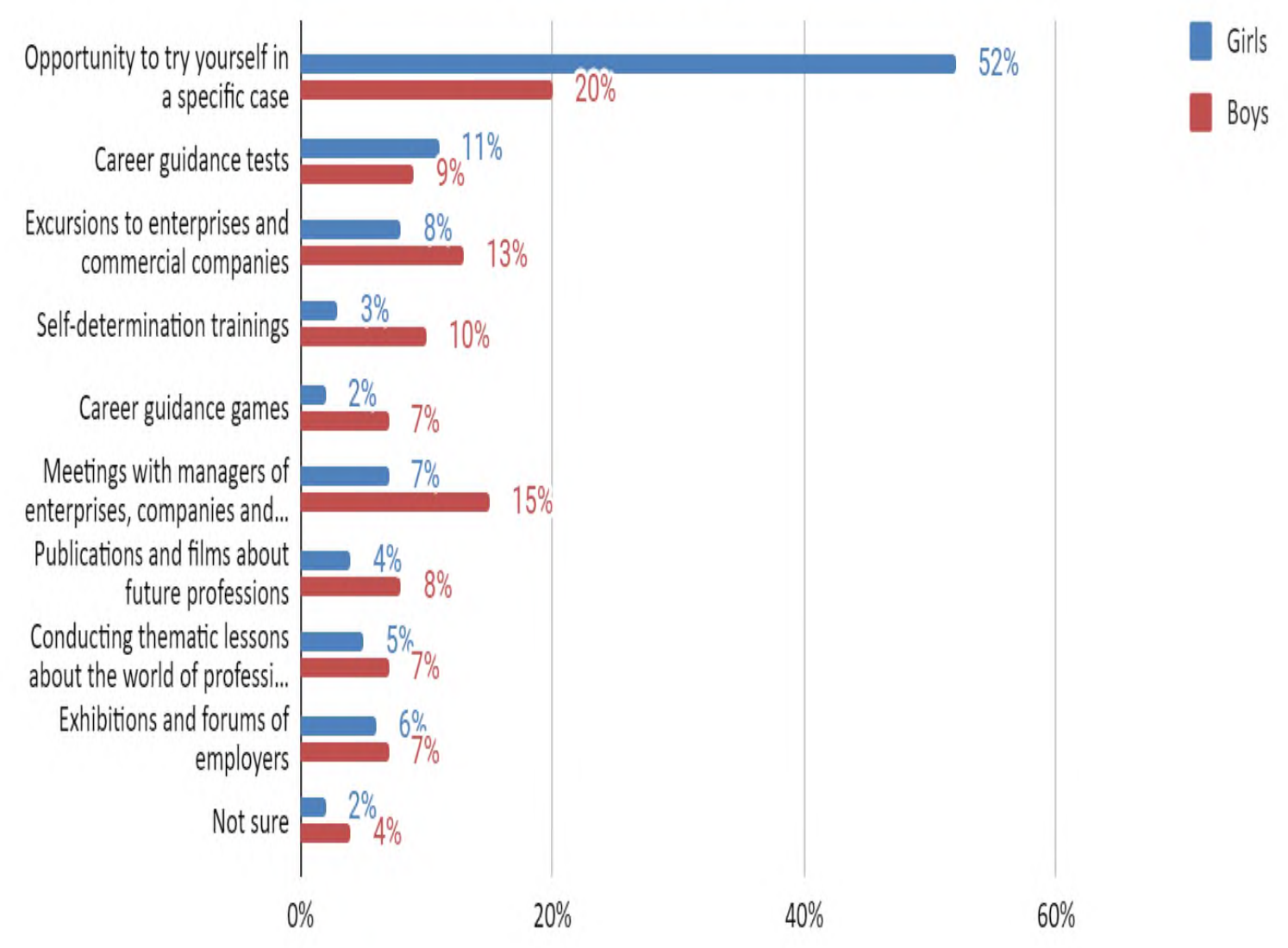

Chart 11. Respondents' answers to the question «Which of the following tools of career guidance, in your opinion, are most conducive to professional self-determination?»

\section{Results and discussion}

The results of our study are partially correlated with the results presented in the work by Blotnicky et al., (2018) regarding the statement that self-efficacy along with knowledge of STEM professions is an important factor in whether adolescents continue their careers in STEM industries. Without setting the task of analyzing gender self-efficacy, we believe that this indicator is present in almost all blocks of our study.

Thus, after conducting research on gender specifics that influence the choice of profession in STEM areas by high school students, we can talk about the following.

1. Students' knowledge in the field of disciplines directly related to STEM, namely, mathematics and natural sciences.

In Ukraine, there are slight differences between girls and boys in the field of interest in natural and mathematics sciences and technological education, with an advantage in favor of boys. Girls are much more likely to state that it is difficult for them to study natural-mathematical subjects and disciplines of a technical profile. In addition, girls compared to boys are more likely to have doubts about their own knowledge in the field of 
natural sciences and mathematics. The boys are also more active in terms of gaining additional knowledge in subjects related to STEM.

2. Career interests, in the context of students' motivation to study STEM disciplines.

In general, we can assume that Ukrainian girls and boys realize that there will be a great demand for STEM specialists in the future. Boys are more confident than girls that a successful career in the future requires good knowledge of mathematics and science. Almost half of all respondents are certain that they have the skills they need to work in STEM fields. At the same time, half of all respondents do not have such self-confidence, and the percentage of insecure girls is slightly higher than boys.

The results of the survey demonstrate a significant gender gap in terms of understanding what career guidance tools should be. In particular, for most girls it is important to try themselves in a particular job, while much fewer boys need it. In general, respondents' responses regarding the effective career guidance tools at school appear to be quite scattered, possibly due to different conceptual approaches used at the state level, different schools, and recruitment companies targeting Ukrainian youth.

3. Students' knowledge of the requirements for STEM professions.

At the level of perception of STEM professions there are certain gender differences. Boys prefer clear and specific activities and areas - design and programming are more interesting for them, and girls prefer scientific and technical creativity and ICT technology in general.

Despite the fact that the results of the study show that the vast majority of respondents surveyed are certain in their own awareness of the possibility of realizing their own knowledge in the field of STEM in the future, the percentage of those who have not decided remains high. The latter may be related to gaps in the career guidance system in Ukrainian schools. In addition, we can state that there is a gender difference in the answers to the questions regarding the motivation to choose STEM profession as promising one.

In general, the difference in the orientations of boys and girls in the field of STEM may be that girls are more likely to draw parallels between STEM and STEAM, focusing not only on the connection of STEM with the natural sciences but also with the humanities. It should be also taken into account that the respondents are students of experimental schools, where attention to STEM education is increased, compared to other educational institutions in Ukraine. In the context of this issue, we fully agree with the conclusions of the study by Blotnicky et al., (2018), in terms of the need to increase awareness, interest of students in STEM careers, we need to pay attention to alternative ways of teaching and assessing disciplines related to STEM.

The finding of a slight gender gap in the perception and assimilation of STEM-related subjects partially confirms the results of the international PISA survey, in which Ukraine participated in 2018. Thus, according to the results of this international study, boys outperformed girls in mathematics by 4.8 points on average in OECD countries and by 7 points in Ukraine (although the difference in average scores is not statistically significant). The difference in performance in science disciplines between boys and girls in Ukraine is almost non-existent (1.7 points in favor of boys), as well as the OECD average (2.8 points in favor of girls) (PISA, 2018).

These data suggest that in Ukraine the relative success of boys compared to the success of girls has the same trend as the OECD average. That is, we see a small but 
existing gap in the level of demonstrated mathematical and natural competencies in favor of boys, despite the fact that more girls than boys agree that learning is important.

Conclusion. The results of the study show that the choice of profession in the field of STEM is influenced by: awareness of the prospects of the future profession; selfconfidence, which is inextricably connected with Ukrainian students; academic success in natural and mathematics sciences and technological education. The interviewed girls, despite the awareness of a high level of understanding of the relevance and prospects of STEM professions, are less likely than boys to choose a profession in this field. The main obstacles in this way, based on the empirical data of our study, are: girls' insecurity in their own knowledge and skills; stereotypical perception of the world of technical professions as male; low level of information and career guidance projects in Ukrainian schools, etc.

The results indicate the importance of finding and expanding opportunities to involve Ukrainian boys and girls in projects that could interest and reveal the scientific potential of students in the fields of STEM. Beyond this, the results articulate the attention of the Ukrainian and world community to the fact that girls need mechanisms different from boys for the implementation of career guidance policy at the school level in the world of technical disciplines. It is also important to draw attention to the general state of career guidance work in Ukrainian schools and the lack of a single state concept of its implementation.

The study is one of the pilot projects in Ukraine and therefore aimed at a general analysis of the state of gender issues in the field of STEM-education. To further delve into the problem, it is necessary to conduct a regression analysis of several variables, in particular, the study of the relationship between career planning in the field of STEM and the type of residence of students (metropolis, city, town, village) and analysis of STEM preferences with reference to academic success of boys and girls.

Acknowledgement. We express our gratitude and deep appreciation to everybody of Principals of Experimental School for their participation in this survey and innovative work for development of STEM-education in Dnipro Region.

\section{References}

Allen, CD. \& Eisenhart, M. (2017). Not Lack of Ability but More Choice: Individual and Gender Differences in Choice of Careers in Science, Technology, Engineering, and Mathematics. Learning $\quad$ Sciences, (3), 407-436 pp. DOI: $10.1080 / 10508406.2017 .1294985$

Asunda, Paul A. (2014) A Conceptual Framework for STEM Integration Into Curriculum Through Career and Technical Education, Journal of STEM Teacher Education: Vol. 49:1,4.

DOI: $10.30707 /$ JSTE49.1Asunda

Bagiati, A. \& Evangelou, D. (2016). Practicing engineering while building with blocks: identifying engineering thinking. European Early Childhood Education Research Journal, 24:1, 67-85 pp. DOI: 10.1080/1350293X.2015.1120521

Becker, K., \& Park, K. (2011). Effects of integrative approaches among science, technology, engineering, and mathematics (STEM) subjects on students' learning: A 
preliminary meta-analysis. Journal of STEM Education: Innovations \& Research, 12 (5-6), 23-37 pp.

Bem S.L. (2004). The lenses of gender: Transforming the debate on sexual inequality. Moscow: ROSSPEN (in Rissian).

Blotnicky, KA, Franz-Odendaal, T., French, F. \& Joy, P. (2018). A study of the correlation between STEM career knowledge, mathematics self-efficacy, career interests, and career activities on the likelihood of pursuing a STEM career among middle school students. International Journal of STEM Education, 5 (1), 22 p. DOI: 10.1186/s40594$\underline{018-0118-3}$

Blums, A., Belsky, J., Grimm, K., \& Chen, Z. (2017). Building links between early socioeconomic status, cognitive ability, and math and science achievement. Journal of Cognition and Development, 18(1), 16-4 pp. DOI:10.1080/15248372.2016.1228652

Bottia, M., Stearns, E., Mickelson, R., Moller, S. \& Valentino, L. (2015). Growing the roots of STEM majors: Female math and science high school faculty and the participation of students in STEM. Economics of Education Review, 45, 14-27 pp. DOI: 10.1016/j.econedurev.2015.01.002

Buturlina, O.V., Lysokolenko, T.V. \& Dovgal, S.A. (2019). STEM-education in the mirror of sociological research. Scientific and theoretical almanac «Grani», 22 (6). 56-68 pp. DOI: $\underline{10.15421 / 171963}$

Ceci, S. J., \& Williams, W. M. (2007). Why aren't more women in science?: Top researchers debate the evidence. American Psychological Association. DOI: 10.1037/11546-000

Dixon, R. A., \& Brown, R. A. (2012). Transfer of Learning: Connecting Concepts during Problem Solving. Journal of Technology Education, 24(1), 2-17 pp.

Gabay-Egozi, L., Shavit, Y., \& Yaish M. (2015) Gender Differences in Fields of Study: The Role of Significant Others and Rational Choice Motivations, European Sociological Review, 31, (3), 284-297 pp. DOI: 10.1093/esr/jcu090

Letter Institute of Education Content Modernization (IECM 2015). On introduction of directions of STEM-education. 2.1, 10-14. Retrieved from: https://drive.google.com/file/d/0B3m2TqBM0APKd2tFMXVtZU96NzA/view (in Ukrainian).

Lauretis T. (1987). Technologies of Gender: Essays on theory, film and fiction. Bloomington, Indianapolis: Indiana university press.

Letter Institute of Education Content Modernization (IECM 2019). Methodical recommendations for the development of STEM-education in general secondary and out-of-school education institutions in the 2019/2020 academic year. 122.08.2019 № 22.1 / 10-2876. Retrieved from: https://imzo.gov.ua/2019/08/23 / lyst-imzo-vid-22-082019-22-1-10-2876-metodychni-rekomendatsii-shchodo-rozvytku stem-osvity-uzakladakh-zahal-noi-seredn-oi-ta-pozashkil-noi -osvity-u-2019-2020-navchal-nomurotsi / (in Ukrainian).

Murphy, S., MacDonald, A., Danaia, L., \& Wang, A. (2018). An analysis of Australian STEM education strategies. Policy Futures in Education, 17 (2), 122-139 pp. DOI: $10.1177 / 1478210318774190$

Order of the Ministry of Education and Science of Ukraine (2016). On the Establishment of a Working Group on the Implementation of Stem-Education in Ukraine, $188 \mathrm{p}$. Retrieved from: 
https://drive.google.com/file/d/0B3m2TqBM0APKSG1MMXREeVFpNDg/view

(in

Ukrainian).

Order of the Ministry of Education and Science of Ukraine (2017). On conducting research and experimental work at the Ukrainian level on the theme: Scientific and methodical principles of creation and functioning of the All-Ukrainian scientific and methodological virtual STEM-center for 2017-2021, 708 p. Retrieved from: https://drive.google.com/file/d/0B3m2TqBM0APKaXJGVlk1bVZ2cFk/view

(in

Ukrainian).

OECD (2015). The ABC of Gender Equality in Education: Aptitude, Behaviour, Confidence. PISA, OECD Publishing. DOI: 10.1787/9789264229945-en

OECD (2016). Education at a Glance 2016. OECD Publishing, Paris. DOI: 10.187/eag-2016-en

Perez, T., Cromley, J. G., \& Kaplan, A. (2014). The role of identity development, values, and costs in college STEM retention. Journal of Educational Psychology, 106(1), 315329 pp. DOI: $\underline{10.1037 / a 0034027}$

Samsudin, M. A., Jamali, S. M., Zain, A. N. M., \& Ale Ebrahim, N. (2020). The Effect of STEM Project Based Learning on Self-Efficacy among High-School Physics Students. Journal of Turkish Science Education, 17 (1), 94-108 pp. DOI: $10.36681 /$ tused.2020.15

Sheffield, R., Koul, R., Blackley, S., \& Maynard, N. (2017). Makerspace in STEM for girls: A physical space to develop twenty-first-century skills. Educational Media International. 54(2), 148-164 pp. DOI: 10.1080/09523987.2017.1362812

Ukrainian Center for Educational Quality Assessment (2019). National report on the results of the international survey on the quality of education PISA-2018. Ukrainian Center for Educational Quality Assessment. Kyiv: UTSOYAO [in Ukrainian]. Retrieved from:

content/uploads/2019/12/PISA 2018 Report UKR.pdf

Wang, MT. \& Degol, J. (2013). Motivational pathways to STEM career choices: Using expectancy-value perspective to understand individual and gender differences in STEM fields. Developmental Review, $33(4), 304-340$ pp. DOI: 10.1016/j.dr.2013.08.001

Wang, M. \& Degol, J.L. (2017) Gender Gap in Science, Technology, Engineering, and Mathematics (STEM): Current Knowledge, Implications for Practice, Policy, and Future Directions. Educ Psychol Rev 29, 119-140. DOI: 10.1007/s10648-015-9355-X

Wang, M.T., Eccles, J. S., \& Kenny, S. (2013). Not Lack of Ability but More Choice: Individual and Gender Differences in Choice of Careers in Science, Technology, Engineering, and Mathematics. Psychological Science, 24(5), 770-775 pp. DOI: $10.1177 / 0956797612458937$

Xie Y., Fang, M. \& Shauman, K. (2015). STEM Education. Annual Review of Sociology, 41:1. 331-357. DOI: https://doi.org/10.1146/annurev-soc-071312-145659

Zeldin, A. \& Pajares, F. (2000). Against the Odds: Self-Efficacy Beliefs of Women in Mathematical, Scientific, and Technological Careers. American Educational Research Journal, 37 (1), 215-246 pp, DOI: 10.3102/00028312037001215. 


\section{ОКСАНА БУТУРЛІНА,}

Комунальний заклад вищої освіти «Дніпровська академія неперервної освіти» Дніпропетровської обласної ради, м.Дніпро, Україна buturlina71@gmail.com, ORCID: 0000-0002-9603-4752

\section{ТЕТЯНА ЛИСОКОЛЕНКО,}

Комунальний заклад вищої освіти «Дніпровська академія неперервної освіти» Дніпропетровської обласної ради, м.Дніпро, Україна lusokolenko@gmail.com, ORCID: 0000-0003-1545-8682

\section{СЕРГІЙ ДОВГАЛЬ,}

Комунальний заклад вищої освіти «Дніпровська академія неперервної освіти» Дніпропетровської обласної ради, м.Дніпро, Україна sdovgal2010@gmail.com, ORCID: 0000-0002-7134-7488

\section{ДОСЛІДЖЕННЯ ВПРОВАДЖЕННЯ SТЕМ-ОСВІТИ В УКРАЇНІ: ГЕНДЕРНИЙ АСПЕКТ}

Враховуючи важливість подолання дефіичиту кадрів на ринку STEM, изе дослідження має на меті представити аналіз гендерних характеристик, які впливають на вибір професії стариокласниками. Сочіологічне опитування проводилось за допомогою онлайн-методу - опитування з використанням сервісу Google Forms. Вибірка дослідження складалася з 431 респондента -учня 11 класу (з яких 230 дівчат та 201 хлопецьь), які навчалися в експериментальних загальноосвітніх закладах Дніпропетровської області. Методологія охоплює такі аспекти, як знання учнів з математики та природничих наук; кар'срні інтереси в контексті мотивації учнів до вивчення дисциплін STEM; знання старшокласників вимог до кар'єри STEM. Порівняння відповідей респондентів чоловічої та жіночої статі, уможливило проведення паралелей щзодо гендерних відмінностей у галузі професійних уподобань опитаних учнів стариих класів у контексті STEM-освіти. Таким чином, після проведення дослідження гендерних особливостей, щуо впливають на вибір професії в сферах STEM старшокласниками, можна говорити про наступне. Отримані результати показують, щуо між дівчатами та хлопцями існують незначні відмінності у зацікавленості природничо-математичними науками та технологічної освіти з перевагою на користь хлопчиків. Результати свідчать про те, щзо на вибір професії старшокласниками у галузі STЕМ впливає усвідомлення перспектив майбутньої кар'єри та впевненість у собі, шчо пов'язано з академічними успіхами учнів у математичній, науково-технічній освіті. Проведене дослідження $є$ одним із пілотних в Україні. Для подальшого заглиблення у поставлену проблему потрібне проведення регресійного аналізу за кількома змінними, зокрема, дослідження взаємозв'язку між плануванням кар'єри у сфері STEM та типом проживанням учнів (мегаполіс, місто, селище, ОТГ) та аналізу STEM-преференцій, у прив'язияі до академічної успішності хлопизів та дівчат.

Ключові слова: гендер, інновачійні технологї, освіта в Украӥні, STEM. 


\section{ОКСАНА БУТУРЛИНА,}

Коммунальное учреждение высшего образования «Днепровская академия непрерывного образования» Днепропетровского областного совета, Днепр, Украина buturlina71@gmail.com, ORCID: 0000-0002-9603-4752

\section{ТАТЬЯНА ЛИСОКОЛЕНКО,}

Коммунальное учреждение высшего образования «Днепровская академия непрерывного образования» Днепропетровского областного совета, Днепр, Украина lusokolenko@gmail.com, ORCID: 0000-0003-1545-8682

\section{СЕРГЕЙ ДОВГАЛЬ,}

Коммунальное учреждение высшего образования «Днепровская академия непрерывного образования» Днепропетровского областного совета, Днепр, Украина sdovgal2010@gmail.com, ORCID: 0000-0002-7134-7488

\section{ИССЛЕДОВАНИЕ ВНЕДРЕНИЯ УТЕМ-ОБРАЗОВАНИЯ В УКРАИНЕ: ГЕНДЕРНЫЙ АСПЕКТ}

Учитывая важность преодоления дефицита кадров на рынке STEM, это исследование направлено на представление анализа гендерных характеристик, влияюших на вылор профессии старшеклассниками. Социологический опрос проводился с помощьью онлайн-метода - опрос с использованием сервиса Gооgle Forms. Выборка исследования состояла из 431 респондента - учашихся 11 классов (в том числе 230 девочек и 201 мальчика), которые учились в экспериментальных общеобразовательных школах Днепропетровской области. Методология охватыввает такие аспекты, как знания учашихся по математике и естественнылм наукам; карьерные интересы в контексте мотивации учащиихся к изучению дисциплин STEM; знания старшеклассниками требований $к$ карьере STEM. Сравнение ответов респондентов мужского и женского пола, сделало возможным проведение параллелей гендерных различий в области профессиональных предпочтений опрошенных учащуихся старших классов в контексте STEMобразования. Таким образом, после проведения исследования гендерных особенностей, влияющих выбора профессии в сферах STEM старшеклассниками, можно говорить о следующем. Полученные результаты показывают, что между девочками и мальчиками существуют незначительные расхождения в сфере интересов естественно-математических наук и технологического образования с перевесом в пользу мальчиков. Результаты свидетельствуют о том, что на выбор профессии старшеклассниками в области STEM влияет осознание перспектив будущей карьеры и уверенность в себе, что связано с академическими успехами учашихся в математике и научно-техническом образовании. Проведенное исследование является одним из пилотных в Украине. Для дальнейшего углубления в поставленную проблему требуется проведение регрессионного анализа по нескольким переменным, в частности, исследования взаимосвязи между 
планированием карьеры в сфере STEM и типом проживания учашчихя (мегаполис, город, поселок, ОТГ) и анализа STEM-преференций, в непосредственной связке с академической успеваемостью ребят.

Ключевые слова: гендер, инновационные технологии, образование в Украине, STEM.

Стаття надійшла до редакції 06.07.2021

Прийнято до друку 23.09 .2021 